\title{
Gonadectomie 2.0: nieuwe inzichten over de langetermijneffecten bij honden
}

\author{
Gonadectomy 2.0: novel insights into the long-term effects in dogs
}

\author{
J. Lannoo, G. Domain, A. Van Soom, E. Wydooghe
}

Vakgroep Voortplanting, Verloskunde, en Bedrijfsdiergeneeskunde, Faculteit Diergeneeskunde, UGent, Salisburylaan 133, B-9820 Merelbeke

Eline.Wydooghe@Ugent.be

voortplanting.gezelschapdieren@ugent.be

\section{AMENVATTING}

Argumenten tegen gonadectomie worden steeds vaker gehoord. Nieuwe studies tonen immers aan dat de ingreep voor de hond negatieve gevolgen kan hebben die op het eerste zicht niet rechtstreeks met het weghalen van de gonaden of de geslachtshormonen verband houden. In het voorliggende overzichtsartikel wordt de huidige literatuur over de langetermijngevolgen van gonadectomie op de gezondheid van de hond beschreven. De belangrijkste reden voor het ovariectomiseren van een teef is de afname van het risico op pyometra en mammatumoren in vergelijking met intacte teven. De beschermende werking tegen mammatumoren is de reden waarom de operatie vaak op jonge leeftijd uitgevoerd wordt. Echter, in recent onderzoek werd aangetoond dat gewrichtsproblemen en bepaalde niet-genitale neoplasieën vaker voorkomen bij honden na gonadectomie, vooral bij prepuberaal geopereerde dieren. De resultaten van deze studies tonen grote rasverschillen aan, waardoor een algemeen advies over gonadectomie voor de hele hondenpopulatie niet realistisch is. De evolutie naar een 'advies op maat' dringt zich op.

\section{ABSTRACT}

In recent years, gonadectomy in dogs has become the subject of growing criticism. Novel studies have demonstrated that this type of surgery can have negative effects on the dog's health, effects that at first sight cannot be linked to the removal of the gonads or the absence of sex steroids. In this review, the literature on the long term-health effects of gonadectomy in dogs is described. The most important medical indication for ovariectomy in a bitch is lowering the risk of pyometra and mammary tumors, diseases which are prevalent in intact bitches. Spaying is often done in young bitches because of the protective effect it has on the development of mammary tumors. However, recent research has shown that orthopedical problems and some non-genital tumors are more prevalent in dogs after gonadectomy, especially if spayed before puberty. Results of these studies also show a major impact of the breed of the dog, hence a general advice for the dog population is not feasible. Veterinarians have to evolve towards a patient-specific advice in this matter.

\section{INLEIDING}

Is het aan te raden om een jonge teef te ovariëctomiseren? Zo ja, op welke leeftijd wordt dit het beste gedaan? En wat met een jonge reu? Het is een gesprek dat praktijkdierenartsen wekelijks met eigenaars voeren en waarover zowel bij eigenaars als dierenartsen veel verschillende meningen bestaan. De voordelen van de operatie zijn voor sommigen belangrijker dan de nadelen, terwijl het voor anderen net omgekeerd kan zijn.
De onderliggende redenen waarom eigenaars ervoor kiezen gonadectomie bij hun hond electief te laten uitvoeren, zijn voor de hand liggend: het steriel maken van de reu of teef, het vermijden van de ongemakken gerelateerd aan loopsheid en het vermijden van aandoeningen van het genitale stelsel. Wat de reu betreft, meldt $58 \%$ van de eigenaars dat het corrigeren of vermijden van ongewenst gedrag een reden is om hun hond te laten castreren (Roulaux et al., 2020). De keuze voor gonadectomie wordt mede bepaald door factoren, zoals de culturele achtergrond, de wetgeving 
van een bepaald land, de economische status van de eigenaar, het geslacht van de eigenaar en de relatie tussen eigenaar en hond (Downes et al., 2015). In het beslissingsproces van de eigenaar voor electieve gonadectomie speelt het advies van de dierenarts een belangrijke rol (Roulaux et al., 2020). In landen zoals het Verenigd Koninkrijk en in mindere mate ook België wordt gonadectomie door veel dierenartsen aangeraden bij niet-fokdieren in het kader van de gezondheid van het dier en het gemak voor de eigenaar. Bijgevolg is in het Verenigd Koninkrijk meer dan de helft van de honden gegonadectomiseerd (Diesel et al., 2010). Dit staat in groot contrast met de situatie in Zweden, waar minder dan tien procent van de hondenpopulatie gegonadectomiseerd is (Egenvall et al., 1999; Sallander et al., 2001). Hier was het jarenlang bij wet verboden om gezonde honden te castreren en nog steeds staat in Zweden de integriteit van het dier centraal.

De laatste jaren geven eigenaars of fokkers er steeds vaker de voorkeur aan om een reu of teef niet te laten opereren. Sommige fokkers waarschuwen nieuwe hondeneigenaars zelfs in het aankoopcontract voor de mogelijke nadelige gevolgen van gonadectomie. Deze bezorgdheid wordt gevoed door een mogelijke overinterpretatie van een aantal recent verschenen onderzoeken waarbij de negatieve impact van castratie aangetoond wordt op het ontstaan van gewrichtsaandoeningen en niet-genitale neoplasieën. Eigenaars vormen vaak hun mening over gonadectomie gebaseerd op de informatie die hun dierenarts hen verstrekt, maar ook op basis van roddels en misvattingen (McKenzie, 2010).

Gezien het als dierenarts belangrijk is om eigenaars nauwkeurige en relevante informatie te verstrekken op basis van de huidige wetenschappelijke kennis, wordt in dit artikel een overzicht gegeven van de voor- en nadelen van gonadectomie op lange termijn. Bijkomend wordt besproken waarom sommige onderzoeken een vertekend beeld kunnen geven van deze materie.

\section{VOORDELEN VAN GONADECTOMIE}

\section{Teef}

Het chirurgisch wegnemen van de gonaden heeft een beschermende werking tegen meerdere aandoeningen van het genitale stelsel. De belangrijkste medische redenen om vrouwelijke honden preventief te gonadectomiseren zijn het beduidend verkleinen van het risico op mammatumoren (Schneider et al., 1969) en het vermijden van pyometra. De hondenpopulatie van landen waar weinig electieve gonadectomieën worden uitgevoerd, vormt een ideale populatie om de prevalentie van deze aandoeningen te bestuderen. Zo werden in een Zweedse studie 260000 teven tot de leeftijd van tien jaar opgevolgd en werd de prevalen- tie van mammatumoren en pyometra nagegaan (Jitpean et al., 2012). Gemiddeld werd bij 19-24\% van de teven pyometra (Egenvall et al., 2001; Jitpean et al., 2012) en bij 13\% een mammatumor gediagnosticeerd (Jitpean et al., 2012) vóór de leeftijd van tien jaar.

Beide aandoeningen zijn leeftijdsafhankelijk. Het risico op pyometra of een mammatumor neemt toe met een stijgende leeftijd (Egenvall et al., 2001; Jitpean et al., 2012). Op het moment van de diagnose zijn teven met pyometra gemiddeld vijf tot zeven jaar oud (Jitpean et al., 2012; Melandri et al., 2019) en gemiddeld acht tot tien jaar bij de diagnose van een mammatumor (Jitpean et al. 2012). Hierbij kan de bedenking gemaakt worden dat de prevalentie maar ook de gemiddelde leeftijd mogelijk hoger zouden zijn, indien de teven in deze studie ook nog opgevolgd werden na de leeftijd van tien jaar.

In de Zweedse populatie werd bijna één op drie van de gevolgde teven vóór de leeftijd van tien jaar gediagnosticeerd met ofwel pyometra, ofwel een mammatumor, ofwel beide. Dit varieerde echter van $9 \%$ tot $73 \%$ naargelang het ras waartoe de teef behoorde (Jitpean et al., 2012). Dit toont aan dat de gevoeligheid voor het ontwikkelen van pyometra of mammatumoren rasafhankelijk is (Egenvall et al., 2001; Niskanen en Thrusfield, 1998) (Tabel 1). Rivera et al. stelden in 2009 vast dat twee humane borstkankergenen bij de Engelse springerspaniël geassocieerd waren met het optreden van mammatumoren en dat er dus een erfelijke component was. De rasverschillen in de gevoeligheid voor beide aandoeningen vormen een belangrijk gegeven om mee te nemen bij het advies op maat over het al of niet aanraden van gonadectomie bij een individuele hond.

Het feit dat er minder mammatumoren gezien worden na vroege gonadectomie is één van de voornaamste redenen om een teef electief te opereren met het oog op haar gezondheid. Dit werd al in 1969 duidelijk aangetoond. Wanneer een teef vóór de eerste loopsheid geovariëctomiseerd wordt, is het risico op een maligne mammatumor slechts $0,5 \%$ van het risico bij een intacte teef (Schneider et al., 1969). Met andere woorden, de kans op een maligne melkkliertumor is bij een prepuberaal gegonadectomiseerde teef tweehonderd keer lager dan bij een intacte teef. Wanneer een teef ovariëctomie ondergaat na haar eerste loopsheid maar vóór ze 2,5 jaar is, dan is het risico 6-8\% van het risico bij een intacte teef (de kans ligt dus 15 keer lager). Wanneer een teef in de studie van Schneider et al. (1969) ouder was dan 2,5 jaar op het moment van sterilisatie, dan was het beschermend effect niet meer significant.

Over het effect van gonadectomie op volwassen leeftijd op het risico op mammatumoren zijn in de literatuur echter tegenstrijdige gegevens te vinden. $\mathrm{Er}$ wordt geen beschermend effect meer gezien bij sterilisatie na vier jaar (Klopfleisch et al., 2011; Schneider et al., 1969). Anderzijds werd in een studie van Krisiansen et al. (2016) bij teven die mastectomie onder- 
gingen een lagere kans op herval gezien bij bepaalde types mammaire carcinomen wanneer tegelijkertijd ook ovariëctomie werd uitgevoerd (Kristiansen et al., 2016). Mammatumoren kunnen zowel progesteron- als oestrogeenreceptoren tot expressie brengen (Chang et al., 2009) en binding van oestrogeen op zijn receptor induceert een pro-tumoreffect in het melkklierweefsel (Torres et al., 2021).

Bij pyometra is er geen leeftijdscomponent voor wat het beschermend effect betreft. Aangezien progesteron een sleutelrol speelt in de ontwikkeling van pyometra, komt deze aandoening bij een geovariëctomiseerde teef niet meer voor ongeacht de leeftijd waarop de operatie werd uitgevoerd. Uitzondering hierop zijn teven met het ovarieel restsyndroom of gecastreerde teven die behandeld worden met exogene oestrogenen of progestagenen. Beide situaties kunnen aanleiding geven tot pyometra of stomppyometra (Hagman, 2018). Omwille van het aanhoudende beschermende effect van gonadectomie op het voorkomen van pyometra kan bij een intacte adulte teef (bijvoorbeeld een fokteef waarmee niet meer gekweekt zal worden) het beste alsnog electieve ovariohysterectomie worden uitgevoerd. Volwassen dieren die al verschillende cycli en/of drachten hebben doorgemaakt, kunnen immers aan milde cysteuze endometriumhyperplasie lijden, wat een voorstadium van pyometra kan zijn; bijgevolg is enkel ovariëctomie in die gevallen niet meer voldoende.

Een derde vaak gehoorde reden om een teef te ovariëctomiseren is het vermijden van schijnzwangerschap. Een schijnzwangerschap treedt typisch op zes tot acht weken na de loopsheid en kan zich uiten in twee verschillende vormen: ofwel als een lichte zwelling van de melkklieren, wat de normale fysiologische situatie is; ofwel als een klinische aandoening met erg gezwollen, melk-producerende melkklieren en onrustig nestgedrag bij de teef, waardoor een behandeling zich opdringt. Schijnzwangerschap komt slechts zelden bij een geovariëctomiseerde teef voor, vooral wanneer de teef tijdens de schijnzwangerschap zelf of tijdens de metoestrus geopereerd werd (Root et al., 2018). Bovendien komen tumoren en cysten van ovaria bij gecastreerde teven niet meer voor. Ook vaginaprolaps, die ontstaat onder invloed van verhoogde oestrogenenconcentraties tijdens de loopsheid, wordt door gonadectomie voorkomen (Post et al., 1991).

Reu

Een aantal duidelijke voordelen van castratie bij de reu zijn het vermijden van testikeltumoren alsook het beduidend verkleinen van het risico op goedaardige prostaathyperplasie en problemen secundair hieraan, zoals prostatitis, prostaatcysten en perineale hernia.

Testikeltumoren zijn niet zeldzaam. Prevalenties tussen 10 en 27\% worden beschreven (Dow, 1962; Grieco et al., 2008; Santos et al., 2000). Bij honden jonger dan tien jaar is testikelneoplasie duidelijk gelinkt aan cryptorchidie (Liao et al., 2009; Romagnoli, 1991). De gemiddelde leeftijd op het moment van diagnose is elf jaar (Manuali et al., 2020) en vormt dus vooral een probleem bij oude reuen. De meerderheid van de testikeltumoren metastaseert niet (Santos et al., 2000). Bijgevolg is castratie op het moment van de diagnose in de meerderheid van de gevallen curatief.

Bijna alle oudere intacte reuen vertonen hyperplasie van de prostaat. Vaak blijft dit echter symptoomloos (Renggli et al., 2010). Wanneer benigne prostaathyperplasie toch aanleiding geeft tot klinische klachten, is castratie bij de diagnosestelling curatief. Daarnaast bestaat er ook een medicamenteuze behandeling, namelijk osateroneacetaat (Niżański et al., 2020). Prostatitis en perineale hernia zijn ernstige secundaire aandoeningen als gevolg van prostaathyperplasie. Deze aandoeningen vereisen naast castratie een specifieke behandeling en volledig herstel is niet altijd mogelijk. Ook perianale tumoren zijn vaak tes-

Tabel 1. De rassen met de hoogste (meer dan $60 \%$ ) en de laagste (minder dan $30 \%$ ) prevalentie van pyometra en/of mammatumoren wanneer opgevolgd tot de leeftijd van tien jaar in een Zweedse rashondenpopulatie (Jitpean et al., 2012).

\begin{tabular}{lclc}
\hline HOOGSTE RISICO* & & LAAGSTE RISICO & Prevalentie \\
\hline Ras & Prevalentie & Ras & $11 \%$ \\
\hline Leonberger & $73 \%$ & Norwich terriër & $16 \%$ \\
Ierse wolfshond & $69 \%$ & Greyhound & $18 \%$ \\
Berner Sennen & $69 \%$ & Siberian husky & $18 \%$ \\
Duitse dog & $68 \%$ & Tibetaanse spaniël & $19 \%$ \\
Staffordshire bulterriër & $66 \%$ & Border collie & $20 \%$ \\
Rottweiler & $65 \%$ & Gordon setter & $21 \%$ \\
Vlaamse bouvier & $62 \%$ & Dwergkeeshond & $22 \%$ \\
Doberman & $62 \%$ & Shiba Inu & $22 \%$ \\
Bull terriër & $60 \%$ & Maltezer & $27 \%$ \\
Airedale terriër & $60 \%$ & Jack russel terriër & $28 \%$ \\
\end{tabular}

*De rassen met het hoogste risico zijn overwegend grote en reuzenrassen, die sneller verouderen dan de rassen met het laagste risico (meestal kleine en middelgrote rassen) die op de leeftijd van tien jaar relatief jonger zijn dan de grote rassen. 
tosteronafhankelijk en verdwijnen meestal na castratie (Pisani et al., 2006).

Een belangrijke reden voor de eigenaar om een reu te castreren is het vermijden of verbeteren van ongewenst gedrag. Deze indicatie wordt nader besproken bij de voordelen van castratie omdat reuen vaak worden gecastreerd omdat de eigenaar denkt dat zijn hond door castratie gehoorzamer wordt (Roulaux et al., 2020); dit is echter een onjuiste veronderstelling. Zo geeft de helft van de ondervraagde eigenaars in een recente Nederlandse studie aan dat de castratie geen impact had op het gedrag van hun reu. Eén op vijf eigenaars merkte zelfs op dat het gedrag slechter werd na castratie (Roulaux et al., 2020). Eerder onderzoek heeft aangetoond dat castratie enkel invloed heeft op hormonaal gedrag zoals rijgedrag, urine markeren en weglopen. Ook indien dergelijk hormonaal gemedieerd gedrag al aanwezig is bij de puberende of postpuberale hond (Neilson et al., 1997), kan castratie nog met gewenst effect uitgevoerd worden. Vroege, prepuberale castratie om ongewenst gedrag te vermijden zal vaak het ongewenst verdrag verergeren en onzekere of agressieve honden nog onzekerder en agressiever maken (McGreevy et al., 2018). Uit een Nederlandse studie blijkt dat dierenartsen veel vaker castratie aanbevelen dan gedragstherapeuten en hondentrainers, die eerder tegen castratie zijn (Roulaux et al., 2020). Het is dus aangewezen om met castratie te wachten tot de hond de puberteit heeft doorgemaakt. Indien het ongewenste gedrag daarna aanwezig blijft, kan chemische castratie overwogen worden. Zo kan ingeschat worden of castratie het gewenste effect zal hebben. Indien het ongewenste gedrag na het plaatsen van de implantaat echter erger wordt, is dit maar een kortstondig probleem omdat chemische castratie slechts tijdelijk werkt (Goericke-Pesch, 2017).

\section{NADELEN VAN GONADECTOMIE}

\section{Gewichtstoename en obesitas}

Honden hebben na gonadectomie een groter risico op overgewicht, ongeacht op welke leeftijd de ingreep wordt uitgevoerd (Simpson et al., 2019). Ook verliezen ze minder gemakkelijk de extra kilo's. In een grootschalige studie, waarbij 926 obese honden drie maanden op dieet werden gezet, werd aangetoond dat de intacte reuen en teven na het dieet meer gewicht hadden verloren dan de gecastreerde honden (Flanagan et al., 2017). Obesitas is de meest voorkomende aandoening bij honden en wordt geassocieerd met onder meer orthopedische problemen en diabetes mellitus. Hierdoor kan obesitas de levensduur en de levenskwaliteit van huisdieren gevoelig verminderen (German et al., 2012; Kealy et al., 2002). Het is belangrijk om eigenaars attent te maken op deze bijwerking van gonadectomie. Om preventief en curatief dit overgewicht te behandelen is aanpassing van het voe- der na gonadectomie aangewezen (Phungviwatnikul et al., 2020).

\section{Vachtveranderingen}

Castratie resulteert in een wollige vacht met verlies aan kleurintensiteit bij bepaalde hondenrassen. Dit is vooral een esthetisch probleem bij langharige rassen, zoals setters, spaniëls, golden retrievers, berner sennenhonden, newfoundlanders, en dergelijke. Meerdere factoren beïnvloeden de haarcyclus, zoals genetica, omgeving, voeding maar ook cytokines en hormonen. Naast andere hormonen spelen androgenen, oestrogenen en prolactine een rol in de normale haargroei (Bratka-Robia et al., 2002; Craven et al., 2001). Gonadectomie kan aanleiding geven tot significant meer ondervacht en een verminderde kleurintensiteit. De vacht lijkt op de vacht van een jonge pup en wordt ook "puppy coat" genoemd (Figuur 1). In een studie van Reichler et al. (2008) werden zichtbare vachtveranderingen vastgesteld bij drie van de vijftien $(20 \%)$ honden één jaar na gonadectomie, namelijk bij een cockerspaniël, een hovawart en een beagle. Voor hondeneigenaars is dit vaak een onverwacht en ongewenst gevolg van gonadectomie, waarover zij op voorhand geïnformeerd moeten worden.

\section{Urine-incontinentie}

Een andere ongewenste aandoening die mogelijk kan optreden ten gevolge van gonadectomie is urineincontinentie. Dit is vooral een probleem bij vrouwelijke honden van grote rassen. In een studie van O’Neill (2017) in Engeland bij honderdduizend vrouwelijke honden werd een prevalentie van 3\% vastgesteld. Bij geovariëctomiseerde teven van risicorassen loopt dit echter op tot $32,3 \%$ bij de Ierse setter, $21,6 \%$, bij de dobermann en 15,8 \% bij de dalmatiër (O’Neill et al., 2017). Risicofactoren voor het ontwikkelen van urine-incontinentie zijn (1) lichaamsgewicht boven het gemiddelde voor dat ras, (2) toenemende leeftijd en (3) gonadectomie (O’Neill et al., 2017; Pegram et al., 2019). Over de invloed van de leeftijd op het moment van de operatie en urine-incontinentie worden er in de literatuur tegenstrijdige resultaten vermeld. Uit de meest recente studie van Pegram et al. (2019) bij meer dan 70.000 vrouwelijke honden bleek gonadectomie bij teven jonger dan zes maanden oud een verhoogd risico in te houden op urine-incontinentie in vergelijking met teven geopereerd op latere leeftijd. Dit effect is het duidelijkst bij rassen die op volwassen leeftijd meer dan $25 \mathrm{~kg}$ wegen (Byron et al., 2017). Wat het type operatie betreft, is er geen verschil tussen ovariëctomie of ovariohysterectomie en het risico op urine-incontinentie (Van Goethem et al., 2006). Deze aandoening is niet dodelijk, maar is frustrerend voor de eigenaar en kan soms een reden voor euthanasie van de hond zijn, indien de behandeling niet aanslaat.

Bij de reu komt urine-incontinentie algemeen eer- 
der zelden voor. Bij ongeveer $1 \%$ van de mannelijke honden, al kan de prevalentie bij bepaalde risicorassen oplopen tot $8,4 \%$ bij de Ierse setter en $6,9 \%$ bij de foxterriër. Bij de reu werd aangetoond dat castratie de kans op het optreden van urine-incontinentie niet verhoogt, dit in tegenstelling tot de situatie bij de teef (Hall et al., 2019).

\section{Prostaatneoplasie}

Prostaatneoplasie is een aandoening die bij honden bijna altijd maligne is, maar gelukkig zelden voorkomt (prevalentie $0,35 \%$ ); dit in tegenstelling tot humane prostaatkanker (prevalentie 30\%) (Weaver, 1981). Prostaatneoplasie wordt vooral gezien bij oudere honden (de gemiddelde leeftijd bij diagnose is 8,5 tot 11,2 jaar) en bij honden van middelgrote tot grote rassen (Schrank en Romagnoli, 2020). De diagnose wordt vaker bij gecastreerde honden gesteld dan bij intacte honden, met een bijna 3-4 keer groter risico voor gecastreerde reuen (Bryan et al., 2007; Sorenmo et al., 2003; Teske et al., 2002). Metastasering is bij diagnose vaak al vergevorderd. Dit maakt dat de aandoening een slechte prognose heeft (Schrank en Romagnoli, 2020).

\section{NIEUWE INZICHTEN OVER DE IMPACT VAN GONADECTOMIE}

In een studie van Cooley et al. (2002) werd aangetoond dat rottweilers na gonadectomie een significant hogere kans op osteosarcoom hadden dan intacte honden (Cooley et al., 2002). Meerdere onderzoeken naar deze en andere types van tumoren werden uitgevoerd in de daaropvolgende jaren. Er werd een vast patroon gezien, waarbij honden die gonadectomie hadden ondergaan vaak een hogere kans hadden op bepaalde neoplasieën (osteosarcoom, lymfoom, hemangiosarcoom en mastceltumoren). Bovendien werd aangetoond dat bepaalde orthopedische aandoeningen (ruptuur van de voorste kruisband, elleboogdysplasie en heupdysplasie) vaker blijken voor te komen bij gecastreerde honden dan bij intacte dieren (Arlt, et al. (2017).

\section{Tumoren}

Tumoren zijn een vaak voorkomende oorzaak van sterfte bij honden en zijn een belangrijke reden tot bezorgdheid bij hondeneigenaars. Gonadectomie vermindert de prevalentie van tumoren van het genitale stelsel. Er werd echter aangetoond dat gonadectomie het risico op niet-genitale tumoren bij de hond vergroot. In een studie van Belanger et al. (2017) waarin 90.000 honden van verschillende rassen werden geobserveerd, werd aangetoond dat gonadectomie een significant hoger risico op de ontwikkeling van osteosarcoom, lymfoom, mastceltumoren en hemangiosarcoom inhield voor beide geslachten. In meerdere

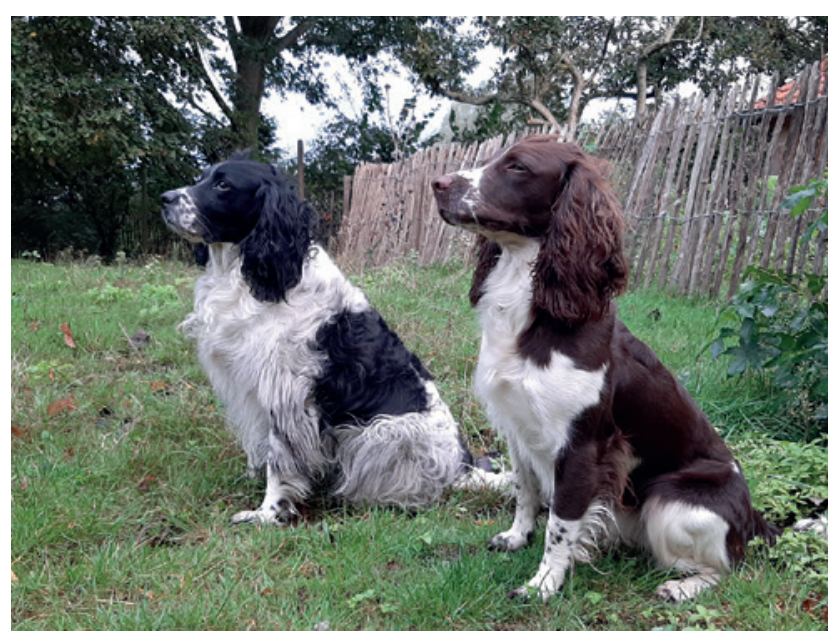

Figuur 1. Impact van gonadectomie op de vachtstructuur. Twee springerspaniëls: de zwart-witte teef op de achtergrond werd geopereerd op volwassen leeftijd en heeft een 'puppy coat'. De bruin-witte teef op de voorgrond is intact en heeft nog een gladde vacht.

rasspecifieke studies bij vizsla's (Zink et al., 2014), golden retrievers en labrador-retrievers (de la Riva et al., 2013; Hart et al., 2014) en Duitse herders (Hart et al., 2016) werd echter aangetoond dat het risico op bepaalde tumoren na castratie afhangt van ras en geslacht. Bij vizsla's werd in een studie van Zink et al. (2014) bijvoorbeeld vastgesteld dat het risico op lymfoom zowel bij de reu als de teef 4,3 keer groter was na gonadectomie dan bij intacte honden. Bij labradorretrievers en Duitse herders had gonadectomie in een onderzoek van Hart et al. $(2014,2016)$ echter geen impact op het risico op lymfoom. Hetzelfde werd gezien voor golden retriever teven (Hart et al. 2014). In een studie van de la Riva et al. (2013) had een goldenretriever reu die vóór de leeftijd van één jaar gecastreerd werd, drie keer zoveel kans om een lymfoom te ontwikkelen dan een intacte reu. In de voorgenoemde rasspecifieke studies werd bovendien een impact aangetoond van gonadectomie op het risico op osteosarcoom, mastceltumoren en hemangiosarcoom. Deze impact was verschillend van ras tot ras en mogelijk ook verschillend tussen reu en teef van hetzelfde ras. Ondanks de verschillen tussen de rassen werd in de studies unaniem vastgesteld dat gonadectomie nooit een beschermend effect uitoefent op het optreden van deze tumoren.

Ook in een aantal niet ras-specifieke studies werd het verband aangetoond tussen gonadectomie en het risico op deze tumoren. In een studie bij meer dan twee miljoen honden werd recent het verband aangetoond tussen gonadectomie en de ontwikkeling van hemangiosarcoom. Hieruit bleek dat zowel de reu als de teef na gonadectomie een groter risico lopen op de ontwikkeling van hemangiosarcoom in het algemeen en meer specifiek voor de ontwikkeling van hemangiosarcoom ter hoogte van de milt (Robinson et al., 2020). In twee andere studies bij Duitse herders en labrador-retrievers werd geen link gevonden tussen gonadectomie en hemangiosarcoom, terwijl deze rassen 
gepredisponeerd zijn voor hemangiosarcoom (Hart et al., 2014; 2016). Een mogelijke verklaring hiervoor is dat de honden hier slechts opgevolgd werden tot de leeftijd van acht jaar, terwijl deze tumor vaker gezien wordt bij oudere honden, met een gemiddelde leeftijd van tien jaar bij diagnose (Brown et al., 1985).

Het is nog niet duidelijk hoe het toegenomen risico op tumoren na castratie kan verklaard worden. Een van de hypothesen is de invloed van een verhoogde luteïniserend-hormoon (LH)-concentratie na gonadectomie (Kutzler, 2020). Na gonadectomie stijgt de concentratie aan LH tot dertig maal in vergelijking met intacte, adulte honden door het wegvallen van het negatief feedback mechanisme vanuit de gonaden (Beijerink et al., 2007). Receptoren voor dit LH-hormoon zijn niet enkel aanwezig in het genitale stelsel, maar ook in andere weefsels van het lichaam. Hun functie daar is tot nu toe echter onbekend. Zo konden LH-receptoren geïdentificeerd worden in het heupgewricht maar onder meer ook in hemangiosarcoom (Kutzler, 2020). Het zou dus kunnen dat de hoge LHgehalten bepaalde cellen tumoraal doen ontaarden, maar verder onderzoek hierover is noodzakelijk.

\section{Orthopedische aandoeningen}

Orthopedische aandoeningen, zoals ruptuur van de craniale kruisband, elleboog- en heupdysplasie zijn op zich geen levensbedreigende aandoeningen, maar hebben een impact op de fysieke prestaties en levenskwaliteit van de patiënt. Een behandeling voor deze aandoeningen kan bovendien vrij duur uitvallen voor de eigenaars.

Het risico op een ruptuur van de voorste kruisband is twee tot drie keer zo hoog na gonadectomie, zowel bij de reu als bij de teef (Witsberger et al., 2008). Het verhoogde risico bestaat vooral wanneer de gonadectomie uitgevoerd wordt vóór de leeftijd van zes maanden bij de labrador-retriever, golden retriever en Duitse herder (Hart et al., 2014; 2016; Simpson et al., 2019). De mogelijke oorzaak is nog niet achterhaald maar men vermoedt dat de voortijdige wegname van hormonen hier een rol speelt. Prepuberale gonadectomie zorgt ervoor dat de groeiplaat van de tibia langer open blijft. Dit resulteert in een conformatieverandering ter hoogte van het kniegewricht, een grotere hoek van het tibiale plateau. De hypothese is dat dit dus meer inwerkende krachten op de craniale kruisband veroorzaakt (de la Riva et al., 2013; Salmeri et al., 1991).

Heupdysplasie is een multifactoriële aandoening. Dus of een genetisch belaste hond de aandoening ontwikkelt en in welke mate hangt af van verschillende omgevingsfactoren, zoals gewicht, hormonen, beweging en groeisnelheid (King, 2017; Ohlerth et al., 2019). In de eerder besproken rasspecifieke studies wordt een verschillende impact van gonadectomie aangetoond op het risico op heupdysplasie. Een gecastreerde, mannelijke golden retriever heeft een hoger risico op de aandoening dan zijn intacte rasgenoot, terwijl er voor teven geen verschil gezien wordt. Bij labradors wordt het omgekeerde aangetoond; een hoger risico bij gesteriliseerde teven, maar geen verschil voor gecastreerde reuen ten opzichte van hun intacte rasgenoten (Hart et al., 2014). Bij de Duitse herder wordt geen significant verschil vastgesteld tussen de prevalentie van heupdysplasie bij intacte en gecastreerde honden, en dit voor beide geslachten (Hart et al., 2016).

Elleboogdysplasie is een verzamelnaam voor verschillende aandoeningen aan het ellebooggewricht, die vooral jonge honden van grote en reuzenrassen treft (Michelsen, 2013). Het is net zoals heupdysplasie een multifactoriële aandoening. Over de impact van gonadectomie op deze aandoening bestaat er in de literatuur nog geen consensus. In een grootschalige studie bij 90.000 honden van verschillende rassen werd geen effect aangetoond van gonadectomie op de ontwikkeling van elleboogdysplasie (Belanger et al. 2017). Bij de rasspecifieke studies kon enkel een effect aangetoond worden bij de mannelijke labrador, waarbij een hoger risico op elleboogdysplasie werd gezien indien de gonadectomie werd uitgevoerd vóór de leeftijd van zes maanden. Bij vrouwelijke labradorretrievers, golden retrievers en Duitse herders werd geen impact van gonadectomie op deze aandoening gevonden (Hart et al., 2014; 2016).

Kleine rassen lijken geen verhoogd risico te hebben op de ontwikkeling van ruptuur van de voorste kruisband, heup- en elleboogdysplasie na gonadectomie. Dit geldt ook voor kruisingen onder de $20 \mathrm{~kg}$ (Hart et al., 2020a; 2020b).

\section{Andere aandoeningen}

De laatste jaren verschenen er tal van publicaties over de impact van gonadectomie op tal van aandoeningen. Zo werd aangetoond dat vroege gonadectomie het risico op discus hernia vergroot bij teven van gevoelige rassen (Belanger et al., 2017). Uit een studie van Dorn en Seath (2018) bij 1694 teckels bleek dat het risico op discus hernia zowel bij de reuen als de teven vooral groter werd wanneer de honden vóór de leeftijd van één jaar gonadectomie hadden ondergaan. Ook voor teven die na de leeftijd van één jaar geovariectomiseerd werden, bleef het risico groter dan bij intacte teven. Daarnaast blijkt dat cognitieve disfunctie, een aandoening die vooral oude, vrouwelijke honden treft, mogelijk vaker gezien wordt na gonadectomie; dit zowel bij de reu als de teef (Azkona et al., 2009).

Bovendien vergroot gonadectomie bij beide geslachten mogelijk het risico op tal van auto-immuunziekten, zoals atopische dermatitis, immuungemedieerde hemolytische anemie en trombocytopenie, myastenia gravis, colitis, immuungemedieerde polyartritis, chronische ontsteking van de darmen en pemfiguscomplex. Het risico op lupus erythematosus stijgt na gonadectomie enkel bij teven (Sundburg et 


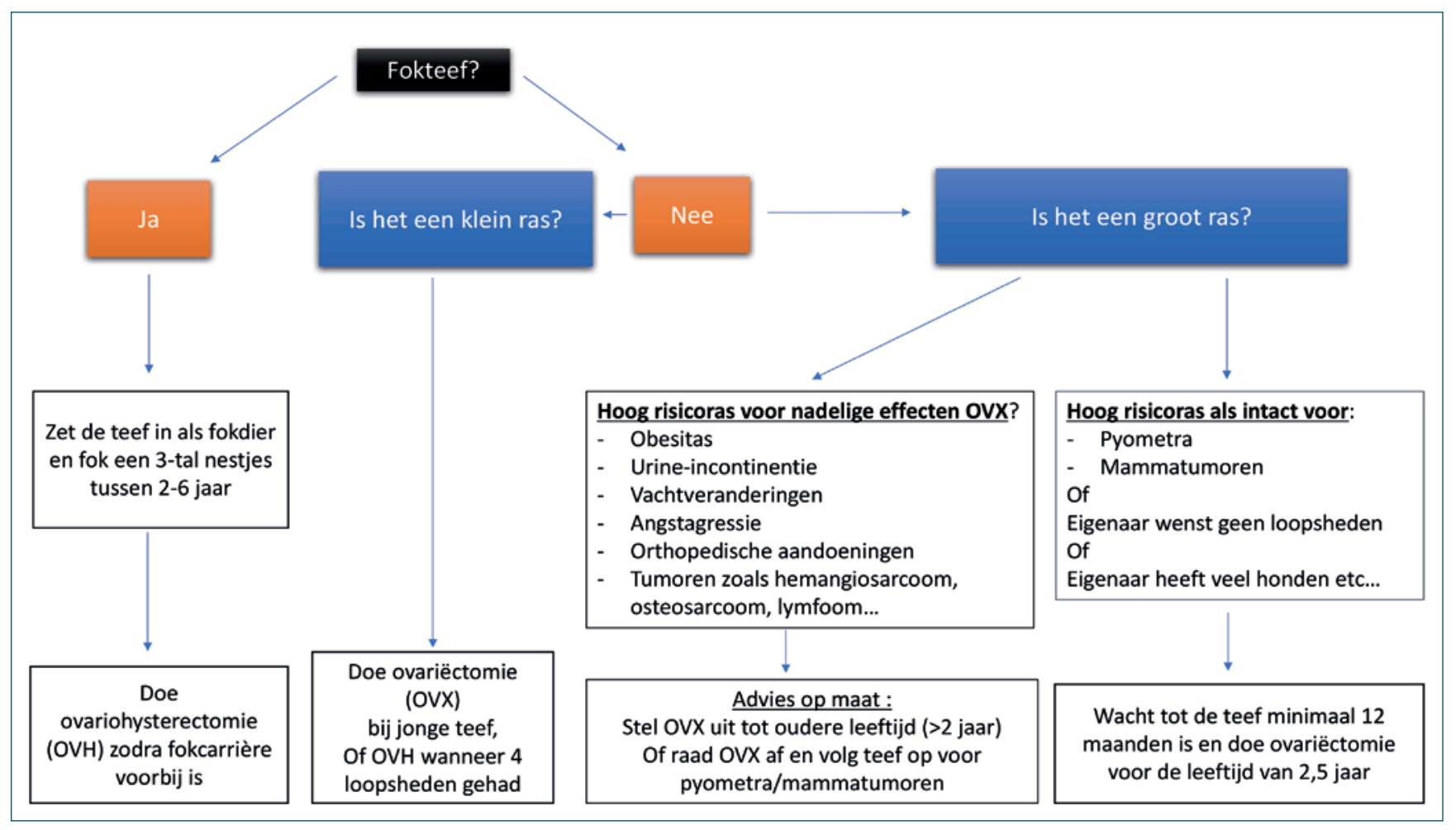

Figuur 2. Flowchart van het beslissingsproces over het al dan niet uitvoeren van gonadectomie bij een teef. Deze flowchart is door de auteurs opgesteld gebaseerd op de huidige wetenschappelijke inzichten en hun eigen logische inzichten, en dient als leidraad voor de dierenarts. Het dient niet als vervanging voor een gedegen anamnese en klinisch onderzoek van de hond. De uiteindelijke beslissing moet altijd in overleg met de eigenaar genomen worden, met inachtneming van de socio-economische omstandigheden van de eigenaar en het welzijn van de hond.

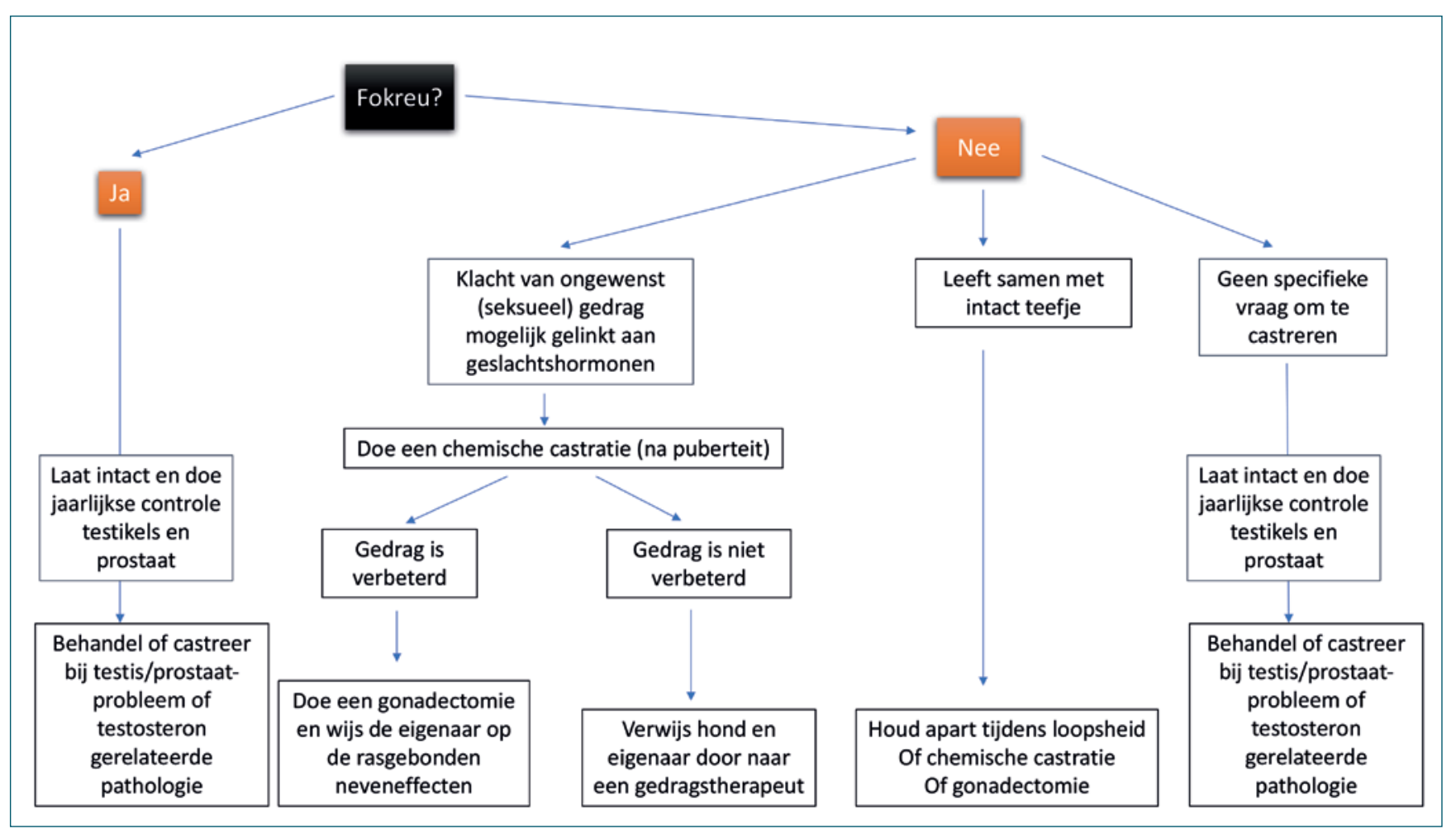

Figuur 2. Flowchart van het beslissingsproces over het al dan niet uitvoeren van gonadectomie bij een reu. Deze flowchart is door de auteurs opgesteld gebaseerd op de huidige wetenschappelijke inzichten en hun eigen logische inzichten, en dient als leidraad voor de dierenarts. Het dient niet als vervanging voor een gedegen anamnese en klinisch onderzoek van de hond. De uiteindelijke beslissing moet altijd in overleg met de eigenaar genomen worden, met inachtneming van de socio-economische omstandigheden van de eigenaar en het welzijn van de hond. 
al., 2016). Over de invloed van gonadectomie op deze aandoeningen is echter verder onderzoek noodzakelijk.

\section{CONCLUSIE}

In dit overzichtsartikel werden de langetermijneffecten van gonadectomie bij honden besproken. Daaruit blijkt dat deze ingreep niet enkel impact heeft op aandoeningen gerelateerd aan het genitale stelsel. De laatste jaren werden verscheidene studies gepubliceerd waarin aangetoond wordt dat gonadectomie ook invloed heeft op de prevalentie van een aantal gewrichtsaandoeningen en niet-genitale tumoren. Een verklaring voor deze impact wordt momenteel nog verder onderzocht.

Op basis van de huidige kennis is het niet evident om in de praktijk één advies te formuleren voor de volledige hondenpopulatie. Er blijken heel wat verschillen te zijn tussen rassen wat het voorkomen van bepaalde aandoeningen en dus ook de impact van gonadectomie op deze aandoeningen betreft.

Bij de teef wordt preventieve gonadectomie voor de meeste rassen zeker nog aanbevolen. De bekende voordelen wegen hier vaak zwaarder door dan eventuele negatieve langetermijneffecten. Wel is het belangrijk na te denken over de leeftijd waarop de ingreep uitgevoerd wordt: bij middelgrote en grote rassen wordt aangeraden om pas na de leeftijd van twaalf maanden gonadectomie uit te voeren (Figuur 2).

Bij de reu zijn er weinig dwingende medische redenen om preventief te castreren. Bij de jaarlijkse controle dienen de testikels en de prostaat bij volwassen en senior-reuen wel goed opgevolgd te worden om tekenen van testikelneoplasie of prostaatvergroting vroeg te kunnen opmerken. Indien men ongewenst gedrag met castratie wil corrigeren, is het aan te raden eerst een chemische castratie uit te voeren, en dit pas na de puberteit, wanneer de reu volledig uitgegroeid is (Figuur 3).

Derhalve moet het advies in de toekomst afgestemd worden op deze huidige kennis en moet geval per geval beoordeeld worden. Ten slotte moet ook rekening gehouden worden met de wensen en verwachtingen van de eigenaar van de hond. Een 'advies op maat' aangaande gonadectomie van de hond dringt zich op.

\section{REFERENTIES}

Arlt S., Wehrend A., Reichler I. M. (2017). Kastration der Hündin - neue und alte Erkenntnisse zu Vor- und Nachteilen. Tierärztliche Praxis Kleintiere 4, 253-263.

Azkona G., García-Belenguer S., Chacón G., Rosado B., León M., Palacio J. (2009). Prevalence and risk factors of behavioural changes associated with age-related cognitive impairment in geriatric dogs. Journal of Small Animal Practice 50, 87-91.
Beijerink N., Buijtels J., Okkens A., Kooistra H., Dieleman S. (2007). Basal and GnRH-induced secretion of FSH and LH in anestrous versus ovariectomized bitches. Theriogenology 67, 1039-1045.

Belanger J.M., Bellumori T.P., Bannasch D.L., Famula T.R., Oberbauer A.M. (2017). Correlation of neuter status and expression of heritable disorders. Canine Genetics and Epidemiology 4, 1-12.

Bratka-Robia C.B., Egerbacher M., Helmreich M., Mitteregger G., Benesch M., Bamberg E. (2002). Immunohistochemical localization of androgen and oestrogen receptors in canine hair follicles. Veterinary Dermatology 13, 113-118.

Brown N., Patnaik A., MacEwen E. (1985). Canine hemangiosarcoma: retrospective analysis of 104 cases. Journal of the American Veterinary Medical Association 186, 5658.

Bryan J.N., Keeler M.R., Henry C.J., Bryan M.E., Hahn A.W., Caldwell C.W. (2007). A population study of neutering status as a risk factor for canine prostate cancer. The Prostate 67, 1174-1181.

Byron J., Taylor K., Phillips G., Stahl M. (2017). Urethral sphincter mechanism incompetence in 163 neutered female dogs: diagnosis, treatment, and relationship of weight and age at neuter to development of disease. Journal of Veterinary Internal Medicine 31, 442-448.

Chang C.-C., Tsai M.-H., Liao J.-W., Chan J.P.-W., Wong M.-L., Chang S.-C. (2009). Evaluation of hormone receptor expression for use in predicting survival of female dogs with malignant mammary gland tumors. Journal of the American Veterinary Medical Association 235, 391396.

Cooley D.M., Beranek B.C., Schlittler D.L., Glickman N.W., Glickman L.T., Waters D.J. (2002). Endogenous gonadal hormone exposure and bone sarcoma risk. Cancer Epidemiology and Prevention Biomarkers 11, 1434-1440.

Craven A., Ormandy C., Robertson F., Wilkins R., Kelly P., Nixon A., Pearson A. (2001). Prolactin signaling influences the timing mechanism of the hair follicle: analysis of hair growth cycles in prolactin receptor knockout mice. Endocrinology 142, 2533-2539.

de la Riva G.T., Hart B.L., Farver T.B., Oberbauer A.M., Messam L.L.M., Willits N., Hart L.A. (2013). Neutering dogs: effects on joint disorders and cancers in golden retrievers. PloS one 8, e55937.

Diesel G., Brodbelt D., Laurence C. (2010). Survey of veterinary practice policies and opinions on neutering dogs. Veterinary Record 166, 455-458.

Dorn M., Seath I.J. (2018). Neuter status as a risk factor for canine intervertebral disc herniation (IVDH) in dachshunds: a retrospective cohort study. Canine Genetics and Epidemiology 5, 11.

Dow C. (1962). Testicular tumours in the dog. Journal of Comparative Pathology and Therapeutics 72, 247-IN232.

Downes M.J., Devitt C., Downes M.T., More S.J. (2015). Neutering of cats and dogs in Ireland; pet owner selfreported perceptions of enabling and disabling factors in the decision to neuter. PeerJ 3, e1196.

Egenvall A., Hagman R., Bonnett B.N., Hedhammar A., Olson P., Lagerstedt A.S. (2001). Breed risk of pyometra in insured dogs in Sweden. Journal of Veterinary Internal Medicine 15, 530-538.

Egenvall A., Hedhammar Å., Bonnett B., Olson P. (1999). Survey of the Swedish dog population: age, gender, breed, location and enrolment in animal insurance. Acta 
Veterinaria Scandinavica 40, 231-240.

Flanagan J., Bissot T., Hours M.-A., Moreno B., Feugier A., German A.J. (2017). Success of a weight loss plan for overweight dogs: The results of an international weight loss study. PloS one 12, e0184199.

German A., Holden S., Wiseman-Orr M., Reid J., Nolan A., Biourge V., Morris P., Scott E. (2012). Quality of life is reduced in obese dogs but improves after successful weight loss. The Veterinary Journal 192, 428-434.

Goericke-Pesch S. (2017). Long-term effects of GnRH agonists on fertility and behaviour. Reproduction in Domestic Animals 52, 336-347.

Grieco V., Riccardi E., Greppi G., Teruzzi F., Iermano V., Finazzi M. (2008). Canine testicular tumours: a study on 232 dogs. Journal of Comparative Pathology 138, 86-89.

Hagman R. (2018). Pyometra in small animals. Veterinary Clinics: Small Animal Practice 48, 639-661.

Hall J., Owen L., Riddell A., Church D., Brodbelt D., O'Neill D. (2019). Urinary incontinence in male dogs under primary veterinary care in England: prevalence and risk factors. Journal of Small Animal Practice 60, 86-95.

Hart B.L., Hart L.A., Thigpen A.P., Willits N.H. (2014). Long-term health effects of neutering dogs: comparison of labrador retrievers with golden retrievers. PloS one 9, e102241.

Hart B.L., Hart L.A., Thigpen A.P., Willits N.H. (2016). Neutering of German Shepherd Dogs: associated joint disorders, cancers and urinary incontinence. Veterinary Medicine and Science 2, 191-199.

Hart B.L., Hart L.A., Thigpen A.P., Willits N.H. (2020a). Assisting decision-making on age of neutering for 35 breeds of dogs: associated joint disorders, cancers, and urinary incontinence. Frontiers in Veterinary Science 7, 388-388.

Hart B.L., Hart L.A., Thigpen A.P., Willits N.H. (2020b). Assisting Decision-making on age of neutering for mixed breed dogs of five weight categories: associated joint disorders and cancers. Frontiers in Veterinary Science 7.

Jitpean S., Hagman R., Ström Holst B., Höglund O., Pettersson A., Egenvall A. (2012). Breed variations in the incidence of pyometra and mammary tumours in Swedish dogs. Reproduction in Domestic Animals 47, 347-350.

Kealy R.D., Lawler D.F., Ballam J.M., Mantz S.L., Biery D.N., Greeley E.H., Lust G., Segre M., Smith G.K., Stowe H.D. (2002). Effects of diet restriction on life span and age-related changes in dogs. Journal of the American Veterinary Medical Association 220, 1315-1320.

King M.D. (2017). Etiopathogenesis of canine hip dysplasia, prevalence, and genetics. Veterinary Clinics: Small Animal Practice 47, 753-767.

Klopfleisch R., Von Euler H., Sarli G., Pinho S., Gärtner F., Gruber A. (2011). Molecular carcinogenesis of canine mammary tumors: news from an old disease. Veterinary Pathology 48, 98-116.

Kristiansen V., Pena L., Diez Cordova L., Illera J., Skjerve E., Breen A., Cofone M., Langeland M., Teige J., Goldschmidt M. (2016). Effect of ovariohysterectomy at the time of tumor removal in dogs with mammary carcinomas: a randomized controlled trial. Journal of Veterinary Internal Medicine 30, 230-241.

Kutzler M.A. (2020). Possible relationship between longterm adverse health effects of gonad-removing surgical sterilization and luteinizing hormone in dogs. Animals: an open access journal from MDPI 10, 599.
Liao A.T., Chu P.-Y., Yeh L.-S., Lin C.-T., Liu C.-H. (2009). A 12-year retrospective study of canine testicular tumors. Journal of Veterinary Medical Science 71, 919-923.

Manuali E., Forte C., Porcellato I., Brachelente C., Sforna M., Pavone S., Ranciati S., Morgante R., Crescio I.M., Ru G. (2020). A five-year cohort study on testicular tumors from a population-based canine cancer registry in central Italy (Umbria). Preventive Veterinary Medicine 185, 105201.

McGreevy P.D., Wilson B., Starling M.J., Serpell J.A. (2018). Behavioural risks in male dogs with minimal lifetime exposure to gonadal hormones may complicate population-control benefits of desexing. PloS one 13, e0196284.

McKenzie B. (2010). Evaluating the benefits and risks of neutering dogs and cats. $C A B \operatorname{Rev} 5,1-18$.

Melandri M., Veronesi M.C., Pisu M.C., Majolino G., Alonge S. (2019). Fertility outcome after medically treated pyometra in dogs. Journal of Veterinary Science 20.

Michelsen J. (2013). Canine elbow dysplasia: aetiopathogenesis and current treatment recommendations. The Veterinary Journal 196, 12-19.

Neilson J.C., Eckstein R.A., Hart B. (1997). Effects of castration on problem behaviors in male dogs with reference to age and duration of behavior. Journal of the American Veterinary Medical Association 211, 180-182.

Niskanen M., Thrusfield M. (1998). Associations between age, parity, hormonal therapy and breed, and pyometra in Finnish dogs. Veterinary Record 143, 493-498.

Niżański W., Ochota M., Fontaine C., Pasikowska J. (2020). Comparison of clinical effectiveness of deslorelin acetate and osaterone acetate in dogs with benign prostatic hyperplasia. Animals 10, 1936.

O’Neill D., Riddell A., Church D., Owen L., Brodbelt D., Hall J. (2017). Urinary incontinence in bitches under primary veterinary care in England: prevalence and risk factors. Journal of Small Animal Practice 58, 685-693.

Ohlerth S., Geiser B., Flückiger M., Geissbühler U. (2019). Prevalence of canine hip dysplasia in Switzerland between 1995 and 2016 - A retrospective study in 5 common large breeds. Frontiers in Veterinary Science 6, 378.

Pegram C., Brodbelt D., Church D., Hall J., Owen L., Chang Y.M., O'Neill D. (2019). Associations between neutering and early-onset urinary incontinence in UK bitches under primary veterinary care. Journal of Small Animal Practice 60, 723-733.

Phungviwatnikul T., Valentine H., de Godoy M.R., Swanson K.S. (2020). Effects of diet on body weight, body composition, metabolic status, and physical activity levels of adult female dogs after spay surgery. Journal of Animal Science 98, skaa057.

Pisani G., Millanta F., Lorenzi D., Vannozzi I., Poli A. (2006). Androgen receptor expression in normal, hyperplastic and neoplastic hepatoid glands in the dog. $R e$ search in Veterinary Science 81, 231-236.

Post K., Van Haaften B., Okkens A.C. (1991). Vaginal hyperplasia in the bitch: Literature review and commentary. The Canadian Veterinary Journal 32, 35.

Reichler I.M., Welle M., Eckrich C., Sattler U., Barth A., Hubler M., Nett-Mettler C.S., Jöchle W., Arnold S. (2008). Spaying-induced coat changes: the role of gonadotropins, GnRH and GnRH treatment on the hair cycle of female dogs. Veterinary Dermatology 19, 77-87.

Renggli M., Padrutt I., Michel E., Reichler I. (2010). Benigne Prostatahyperplasie: Therapiemöglichkeiten beim 
Hund. Schweizer Archiv für Tierheilkunde 152, 279-284.

Rivera P., Melin M., Biagi T., Fall T., Häggström J., Lindblad-Toh K., von Euler H. (2009). Mammary tumor development in dogs is associated with BRCA1 and BRCA2. Cancer Research 69, 8770-8774.

Robinson K.L., Bryan M.E., Atkinson E.S., Keeler M.R., Hahn A.W., Bryan J.N. (2020). Neutering is associated with developing hemangiosarcoma in dogs in the Veterinary Medical Database: An age and time-period matched case-control study (1964-2003). The Canadian veterinary journal/ La Revue Vétérinaire Canadienne 61, 499-504.

Romagnoli S.E. (1991). Canine cryptorchidism. The Veterinary clinics of North America. Small animal practice 21, 533-544.

Root A.L., Parkin T.D., Hutchison P., Warnes C., Yam P.S. (2018). Canine pseudopregnancy: an evaluation of prevalence and current treatment protocols in the UK. BMC veterinary research 14, 1-12.

Roulaux P.E., van Herwijnen I.R., Beerda B. (2020). Selfreports of Dutch dog owners on received professional advice, their opinions on castration and behavioural reasons for castrating male dogs. PloS one 15, e0234917.

Sallander M., Hedhammar Å., Rundgren M., Lindberg J. (2001). Demographic data of a population of insured Swedish dogs measured in a questionnaire study. Acta Veterinaria Scandinavica 42, 1-10.

Salmeri K., Bloomberg M., Scruggs S.L., Shille V. (1991). Gonadectomy in immature dogs: effects on skeletal, physical, and behavioral development. Journal of the American Veterinary Medical Association 198, 1193-1203.

Santos R., Silva C., Ribeiro A., Serakides R. (2000). Testicular tumors in dogs: frequency and age distribution. Arquivo Brasileiro de Medicina Veterinária e Zootecnia $52,25-26$

Schneider R., Dorn C.R., Taylor D. (1969). Factors influencing canine mammary cancer development and postsurgical survival. Journal of the National Cancer Institute 43, 1249-1261.

Schrank M., Romagnoli S. (2020). Prostatic neoplasia in the intact and castrated dog: how dangerous is castration? Animals 10, 85.

Simpson M., Albright S., Wolfe B., Searfoss E., Street K., Diehl K., Page R. (2019). Age at gonadectomy and risk of overweight/obesity and orthopedic injury in a cohort of golden retrievers. PloS one 14, e0209131.

Sorenmo K., Goldschmidt M., Shofer F., Goldkamp C., Ferracone J. (2003). Immunohistochemical characterization of canine prostatic carcinoma and correlation with castration status and castration time. Veterinary and Comparative Oncology 1, 48-56.

Sundburg C.R., Belanger J.M., Bannasch D.L., Famula T.R., Oberbauer A.M. (2016). Gonadectomy effects on the risk of immune disorders in the dog: a retrospective study. BMC Veterinary Research 12, 1-10.

Teske E., Naan E.C., Van Dijk E., Van Garderen E., Schalken J. (2002). Canine prostate carcinoma: epidemiological evidence of an increased risk in castrated dogs. Molecular and Cellular Endocrinology 197, 251-255.

Torres C.G., Iturriaga M.P., Cruz P. (2021). Hormonal carcinogenesis in canine mammary cancer: molecular mechanisms of estradiol involved in malignant progression. Animals 11, 608.

Van Goethem B., Schaefers-Okkens A., Kirpensteijn J. (2006). Making a rational choice between ovariectomy and ovariohysterectomy in the dog: a discussion of the benefits of either technique. Veterinary Surgery 35, 136143.

Weaver A.D. (1981). Fifteen cases of prostatic carcinoma in the dog. Veterinary Record.

Witsberger T.H., Villamil J.A., Schultz L.G., Hahn A.W., Cook J.L. (2008). Prevalence of and risk factors for hip dysplasia and cranial cruciate ligament deficiency in dogs. Journal of the American Veterinary Medical Association 232, 1818-1824.

Zink M.C., Farhoody P., Elser S.E., Ruffini L.D., Gibbons T.A., Rieger R.H. (2014). Evaluation of the risk and age of onset of cancer and behavioral disorders in gonadectomized Vizslas. Journal of the American Veterinary Medical Association 244, 309-319.

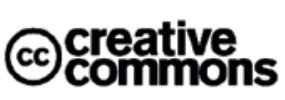

C 2021 by the authors. Licensee Vlaams Diergeneeskundig Tijdschrift, Ghent University, Belgium. This article is an open access article distributed under the terms and conditions of the Creative Commons Attribution (CC BY) license (http://creativecommons.org/licenses/by/4.0/). 